\title{
FROM URBAN GEODIVERSITY TO GEOHERITAGE: THE CASE OF LJUBLJANA (SLOVENIA)
}

\author{
Jure Tičar, Blaž Komac, Matija Zorn, Mateja Ferk, Mauro Hrvatin, Rok Ciglič \\ Anton Melik Geographical Institute, Research Centre of the Slovenian Academy of Sciences and Arts, \\ Ljubljana, Slovenia
}

Manuscript received: March 31, 2017

Revised version: June 19, 2017

Tičar J., Komac B., Zorn M., Ferk M., Hrvatin M., Ciglič R., 2017. From urban geodiversity to geoheritage: the case of Ljubljana (Slovenia). Quaestiones Geographicae 36(3), Bogucki Wydawnictwo Naukowe, Poznań, pp. 37-50. 7 figs, 1 table.

ABstRACT: The city of Ljubljana lies at the intersection of various geomorphological regions that have strongly influenced its spatial organization. Prehistoric settlements were built on marshland, a Roman town was built on the first river terrace of the Ljubljanica River, and in the Middle Ages a town was built in a strategic position between the Ljubljanica River and Castle Hill. The modern city absorbed all usable space between the nearby hills. This paper reviews some relief features in Ljubljana, their influence on the city's spatial development, and urban geoheritage. The results indicate new possibilities for urban geoheritage tourism in the Slovenian capital and its surroundings.

KEY WORDS: geoheritage, geomorphology, urbanization, spatial growth, Ljubljana

Corresponding author: Jure Tičar, jure.ticar@zrc-sazu.si

\section{Introduction}

During the 1990s, geologists and geomorphologists started using the term geodiversity to describe the diversity of nonliving nature (Sharples 1993, Wiedenbein 1994, Zwolinski 2004). The contemporary concept of geodiversity refers to the diversity of nonliving nature in terms of geological elements (rocks, minerals, and fossils), geomorphological elements (forms and processes), and soil (Gray 2013). Geodiversity is an important element of geoheritage that comprises of those elements of the Earth's geodiversity that are considered to have significant scientific, educational, cultural or aesthetic value (IUCN 2017). Currently, there is increasing interest in geotourism (Hose et al. 2011), a type of tourism connecting the diversity of geomorphological and geological elements with their interpretation and recreation (Necheş 2016). Consenquently many geoparks dedicated to protect and to promote the nonliving elements of nature are being established. Numerous geoparks have joined UNESCO's Global Geoparks Network, many of them are being part of the European or Asian Geoparks Network and of great interest of scientific research (Zouros 2004, Frey 2012, Henriques et al. 2012, Buhay, Best 2012).

The assessment of geodiversity is related to comprehensive nature protection and better management of protected areas (Pralong, 2005, Cayla 2009, Hobléa 2009, Reynard 2009, Erhartič, Zorn 2012). Here a distinction should be made between the value of a single geodiversity element and the 
value provided by the diversity of elements in a specific area (Gray 2013), which forms the basis for assessing geodiversity. These geodiversity elements can be assessed in terms of various factors, such as scenic, socioeconomic, cultural, and scientific factors (Panizza 2001). More advanced assessment methods use geographic information systems, which allow quantitative analyses
(Coratza, Giusti 2005). Because such methods can be very complex, new factors were defined while developing the assessment methods; for example, scientific, ecological, aesthetic, cultural, and economic value (Reynard et al. 2007). Quantitative assessment of scientific value of nonliving elements of nature can be obtained with the use of seven criteria: representativeness, key locality,

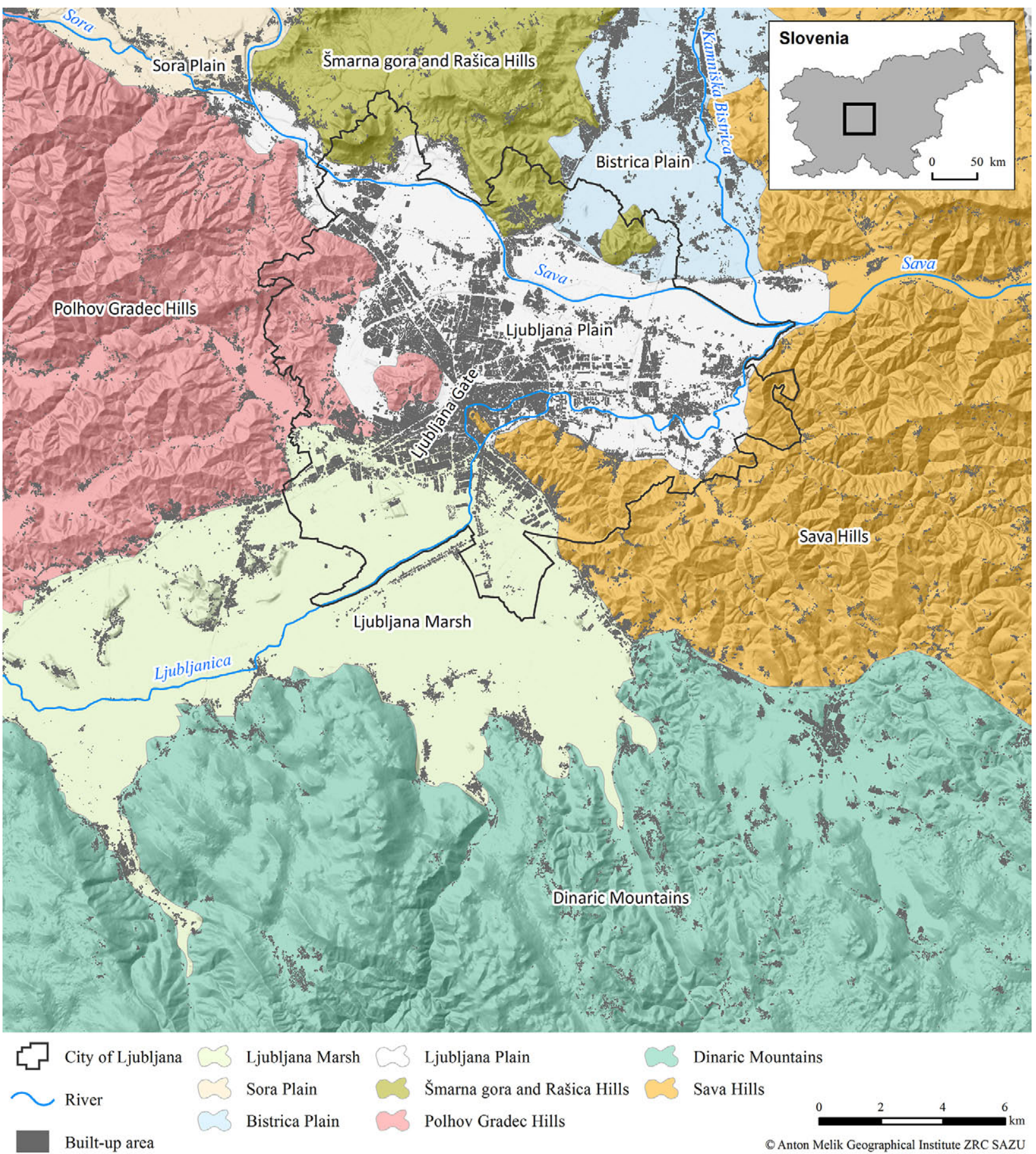

Fig. 1. The city has spread across the flood-safe areas of the Ljubljana Plain to the north and the flood-prone areas of the Ljubljana Marsh to the south. 
scientific knowledge, integrity, geological diversity, rarity and use limitations (Brilha 2016).

Urban geodiversity may simply refer to non-living nature within urban areas, but it can also be considered a factor influencing urban development. In addition, urban geodiversity includes buildings, monuments, and other elements that are not necessarily part of geoheritage, but may represent an important element of promoting and disseminating information about the Earth's surface (Palacio-Prieto 2015). Some authors examine various elements of urban geodiversity in cities (e.g., Turin: Borghi et al. 2015, Mexico City: Palacio-Prieto 2015, Rome: Pica et al. 2016) and others focus on special forms of urban geodiversity, such as parks and gardens (Portal, Kerguillec 2017).

Because of its location at the intersection of four major European geographical units (i.e., the Alps, the Dinaric Mountains, the Pannonian Basin, and the Mediterranean), Slovenia is characterized by a high level of geodiversity (Erhartič 2012, Erhartič, Zorn 2012, Ciglič, Perko 2013, Perko et al. 2017). The Ljubljana area is considered in this paper as a landscape and geodiversity hotspot (Fig. 1), combining an exceptional number of geological and geomorphological features (Perko, Ciglič 2015).

In Slovenia the assessment of geodiversity was carried out relatively early, and the first studies used simple numerical methods to define the degree of landscape attractiveness (Orožen Adamič 1970). The most systematic geomorphosite assessment analyses were carried out in the Alps, around Lake Bled (Erhartič 2010a), and in the Triglav Lakes Valley in Triglav National Park (Erhartič 2012). Some analyses focused on single geomorphological or hydrological forms, such as waterfalls (Erhartič 2010b), or to the loss of geoheritage due to geomorphic processes (Komac et al. 2011). Recent studies have primarily focused on the Dinaric Mountains, where analyses of geodiversity hotspots were carried out in Rakov Škocjan Nature Park (Stepišnik, Repe 2015), Škocjan Caves Regional Park (Stepišnik, Trenchovska 2017), and the Upper Pivka Basin (Trenchovska, Stepišnik 2017). This paper represents the first detailed urban area geomorphosite inventory in Slovenia.

Ljubljana is Slovenia's capital and is located in its centre, in the Ljubljana Basin. The city has an approximate area of $164 \mathrm{~km}^{2}$ (SORS 2016); to the north it extends to the Ljubljana Plain (Ljubljansko polje), which is filled by gravel deposits of the Sava River, and to the south it extends to the Ljubljana Marsh (Ljubljansko barje) filled by the clay deposits of the Ljubljanica River. Ljubljana is bounded by the Polhov Gradec Hills (Polhograjsko hribovje) to the west, Dinaric Mountains (Dinarsko gorovje) to the south and the Sava Hills (Posavsko hribovje) to the east (Fig. 1). In addition to the distribution of natural features, the city's development was strongly influenced by its location at the intersection of major transport routes at the Ljubljana Gate (Ljubljanska vrata) (Pak 1992).

Ljubljana, currently home to 279,756 people or approximately $14 \%$ of Slovenia's total population (SORS 2016), is the administrative, economic, educational, and cultural centre of Slovenia (Nared et al. 2017). Rapid spatial development took place primarily after the Second World War, when the city's population increased by over $120 \%$ (Rebernik 2000). Since Slovenia joined the EU in 2004, Ljubljana has experienced new development; among other things, it was named the European Green Capital in 2016 (European Green Capital 2016).

The analysis of geodiversity in the Ljubljana area used $1 \times 1 \mathrm{~m}$ high-resolution laser scanning data, geological maps, and data on natural heritage. Detailed morphometric relief maps generated from Lidar data provided an insight on well expressed geomorphological features within the study area. However, this method does not provide information about minor geomorphological elements or geomorphosites within a scale of less than $1 \mathrm{~m}$. Information about geodiversity of geomorphosites was additionally identified through detail study of geology maps. Data on the development and spatial growth of the city were obtained from literature. Data on natural heritage provided insight about current state of recognized geomorphosites and was obtained from the Register of Natural Values of the Slovenian Environment Agency. This data contained informations about geoheritage as points (e.g. deposit of fossils or karst caves) or polygons (e.g. rivers, valleys, hills).

This paper presents the history of Ljubljana's development from the perspective of geodiversity. Namely, the development of the city largely depended on the geological, hydrological and 
geomorphological conditions in the area. The paper provides new data on the geodiversity in the Ljubljana area, which can be used for geotourism.

\section{Study area}

Ljubljana is located in central Slovenia in the transition area between the Alps to the north and the Dinaric Mountains to the south. The entire area belongs to the Ljubljana Basin, whose downdrop in the last 3 Ma provided a trap for quaternary sediments that filled the basin several hundreds of metres deep and contributed to high seismic risk - in April 1895 Ljubljana was shaken by a M6.1. earthquake (Ribarič 1982). A ridge of Palaeozoic quartz rocks divides Ljubljana between the northern Ljubljana Plain and the southern Ljubljana Marsh. The Ljubljana Plain contains quaternary fluvio-glacial gravels from the Alps, which are dominantly carbonates and form a series of conglomerate terraces (Fig. 2). The Ljubljana Marsh is mostly filled with finegrained silty sediments originating from karst influx and some gravel and sandy layers deposited as alluvial fans on the northern and eastern rim, at the contact with Palaeozoic mudstones and sandstones (Pleničar 1963, Buser 1974, Grad, Ferjančič 1976, Premru 1983, Buser 2009).

The Ljubljana area is traversed by two large rivers; the Ljubljanica River flowing from the south and crossing the centre of the city, and the

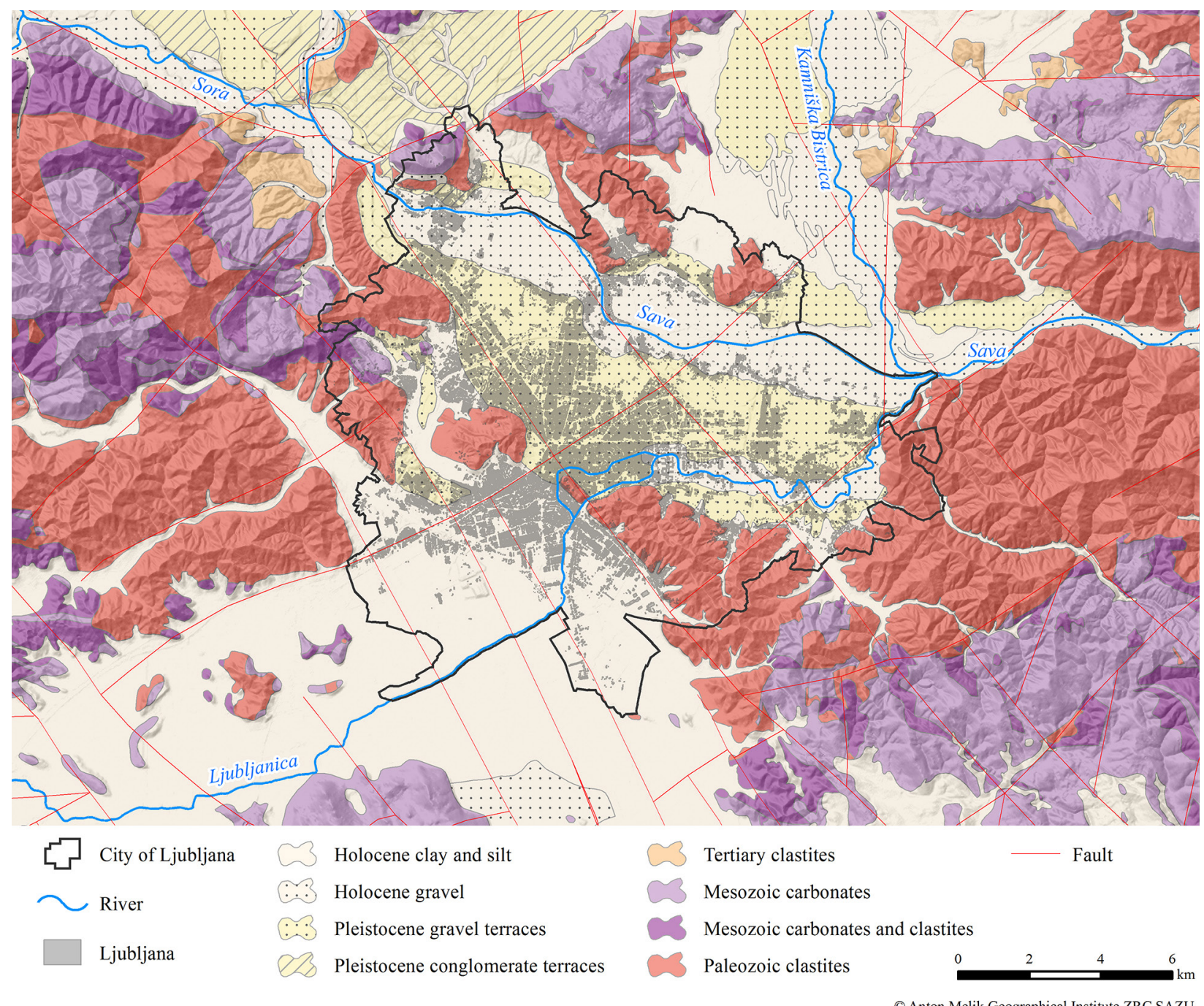

Fig. 2. In addition to hydrological conditions, various rock types in the area have determined the spatial growth of the city. The built-up area concentrated on the flat areas containing Pleistocene and Holocene gravel or conglomerate terraces to the north and Holocene clay and silt to the south. 
Sava River from the north. The southern part of Ljubljana, the Ljubljana Marsh is a flood-prone area where floods would naturally occur periodically, every year. However, in recent centuries extensive hydro-melioration and redirection of the riverbeds has been carried out. Occasional floods still occur along the artificial river beds. The original bed of the Ljubljanica River meandering through the centre of the city is by now entirely channelled, like the rest of its tributaries on urbanized land. Preserved natural morphological features such as natural river beds, meanders, small oxbow lakes, sediment bars, bluffs, flood plains, and bank reshaping processes can still be observed along the Ljubljanica River on the eastern edge of Ljubljana. To the east of Ljubljana there is an important water confluence zone where the Ljubljanica and Kamniška Bistrica rivers join the Sava River.

The basin was filled with sediments in glacial periods while they were eroded in interglacial periods. Past erosion features can still be observed in numerous terraces, especially along the Sava Valley, where current erosion of sediments is still continuing (Premru 1983).

\section{Natural conditions and spatial growth of the city}

Ljubljana was founded in the southern part of the Ljubljana Basin (Fig. 1). The city developed along the $1.5 \mathrm{~km}$-wide Ljubljana Gate (elevation $298 \mathrm{~m}$ ), where the Ljubljanica River broke through a low hilly barrier of Paleozoic clastites. The Ljubljana Gate is the lowest central Slovenian natural passageway between the Alps and the Mediterranean. Natural transportation routes open up in almost all directions in this area (Ogrin 2010).

Four periods of city development can be distinguished in connection with natural features:

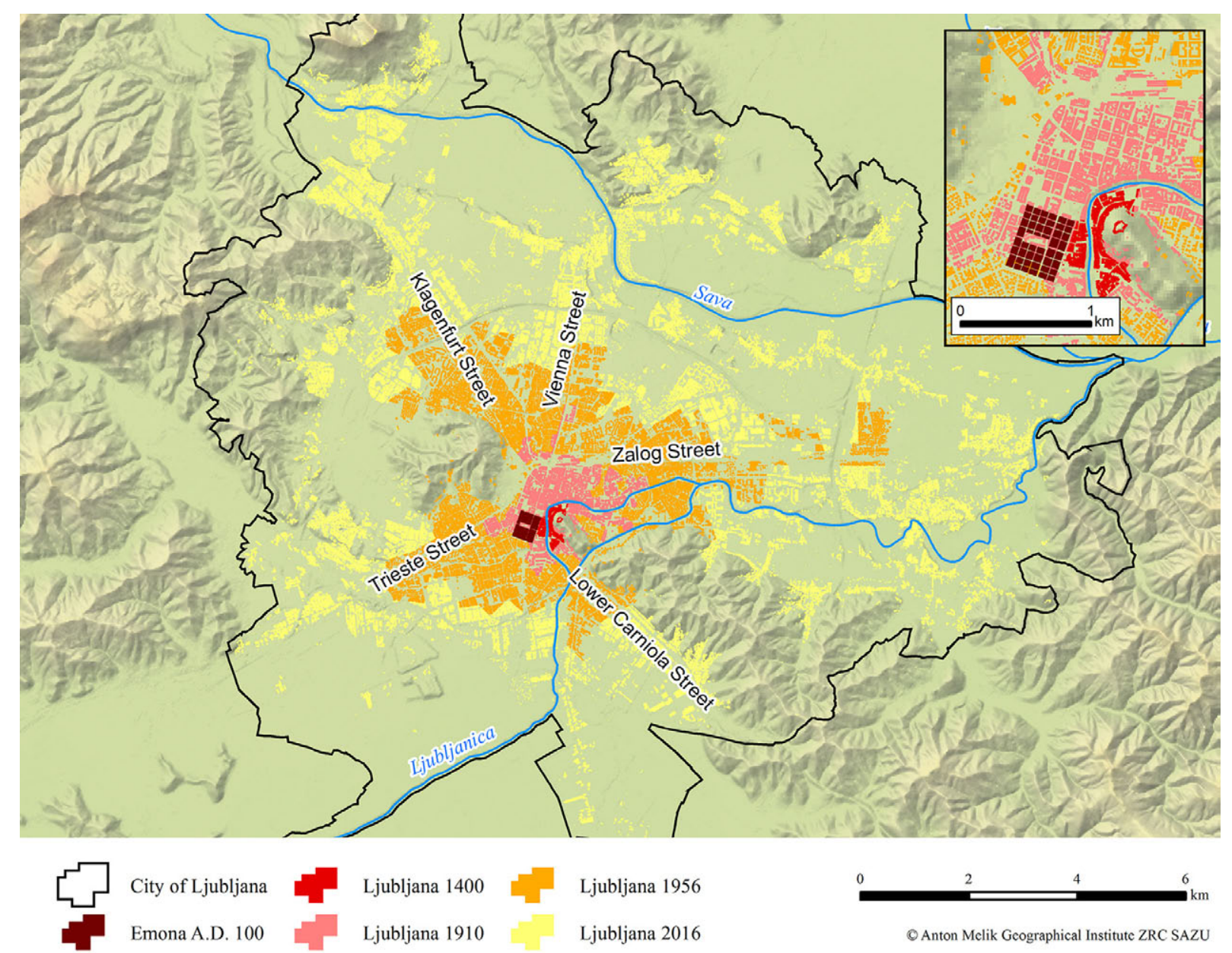

Fig. 3. Spatial growth of the city since the Roman times. 
prehistory, the Roman period, the medieval period and the present. Prehistoric settlements were built in the south in the flat but floodprone Ljubljana Marsh. During the Roman period (Fig. 3), the town of Emona developed on a flood-safe terrace on the northern edge of the Ljubljana Marsh, or the area of the Ljubljana Gate. During the Middle Ages, the town moved somewhat more to the east, to the right bank of the Ljubljanica between the river and Castle Hill (Table 1, Fig. 7), where the first traces of settlement actually go as far back as prehistory and the early Roman era (Melik 1930).

\section{Prehistory}

The first settlements in Ljubljana's wider area (i.e., the Ljubljana Marsh) were built in the fifth millennium BC, or the end of the Late Stone Age. These were pile-dwelling settlements (Velušček 2010), which can be traced up until the middle Bronze Age. At that time, a great part of the marsh was still a shallow lake. Around the mid-second millennium BC at the latest, when the lake turned into a bog, construction of these types of settlements stopped and the settlements moved to the edge (Velušček 2010).

In what is today Ljubljana's old town, more permanent settlement during the prehistoric age (the Bronze Age, and the Neolithic and Palaeolithic) developed at the foot of Castle Hill, where the rudiments of an urban layout were established (Novšak et al. 2017). The foot of Castle Hill on the right bank of the Ljubljanica River offered logistically and strategically favourable conditions for settlement. It was located on the sunny side of the hill with available sources of water. With its location on higher ground, it was also less prone to flooding (Novšak et al. 2017). In the lower part of the area, some flood-protection measures (e.g., a wooden palisade) have been found (Žerjal 2017).

\section{The Roman period}

During the Roman period, a small Roman military camp was established in this area (Novšak et al. 2017), and the later Roman town was built on the left bank of the Ljubljanica, safe from floods. The ancient settlement of Emona and medieval Ljubljana spread on a rock base with good bearing capacity compared to the Ljubljana Marsh and its weaker bearing capacity, where pilings are still used today when building houses (Ogrin 2010).

Emona was built in the mid- $1^{\text {st }}$ century AD and was last mentioned in the $6^{\text {th }}$ century (Bratož et al. 1992). It was created at the edge of a terrace that protected it towards the east (in the direction of the Ljubljanica River) and south in the direction of the Ljubljana Marsh (Melik 1930).

On the right bank of the river the Romans operated a quarry for construction needs. There were several more quarries in the surrounding area (Djurić, Rižnar 2017).

\section{The Middle Ages and early modern period}

After the collapse of the Roman Empire, the settlement went into decline for a few centuries. The Roman trade route through the town and the ancient name of Emona was almost forgotten. It was only after AD 600 to 650, when the area was safe from Avar invasions, that its spatial development started again (Gaspari 2014).

At the beginning of the Middle Ages other settlements, such as Kamnik and Kranj, prevailed over Ljubljana as trade centres along trade routes. A new social division of labour influenced the spatial distribution of towns as craftsmen concentrated in the settlements and noble families were established in $11^{\text {th }}$ and $12^{\text {th }}$ centuries (Gestrin 1989). However, it was only after the $13^{\text {th }}$ century that Ljubljana gained sufficient importance to establish itself as the main commercial centre in Carniola. Until this time, the urban area was limited to the right bank of the Ljubljanica River just below the Castle Hill (Fig. 3).

This strategic location is the location of the present city centre (Grafenauer 1963, Gestrin 1989).

After 1333, Ljubljana became the property of the Habsburg family for few centuries. It became the capital of a new province (Carniola) on the route between Vienna and Trieste and began to flourish, ruled by a local governor. By $15^{\text {th }}$ century, the craftsmen's settlements of Prule, Gradišče, and Poljane had been built in the suburbs. Peasant settlements were located in the south near the Gradaščica River (at Mirje) and in the northwest (at Šiška). Ljubljana surpassed Graz and Wiener Neustadt (both in Austria), while Maribor (northeast Slovenia), Klagenfurt (Austria), Kamnik, and Kranj decreased in power. In the $15^{\text {th }}$ and $16^{\text {th }}$ centuries, a wall was built to protect the town from 
Ottoman raids, and in the $17^{\text {th }}$ century river trade was established on the Ljubljanica and Sava rivers, connecting Ljubljana and Belgrade (Serbia). During this time the colonization of the suburbs began, following the modernization of farming.

\section{Present}

In the second half of the $19^{\text {th }}$ century and the beginning of the $20^{\text {th }}$ century the town spread to the fertile plains on the river terraces and fluvio-glacial sediments to the west and north (Fig. 3 ) as industrialization allowed the town to flourish, especially after the building of the railway in mid-1800s. Then the town radially expanded on the flat areas of the Quaternary terraces to the north and incorporated the nearby villages (Fig. 4). This radial urbanization depended on the main roads, named after their destinations: Celovška cesta (Klagenfurt Street; northwest direction), Tržaška cesta (Trieste Street; southwest direction), Dolenjska cesta (Lower Carniola Street; southeast direction), Dunajska cesta (Vienna Street; north direction) and Zaloška cesta (Zalog Street; east direction). Today, almost all of the flat areas between the Sava River to the north, the Ljubljana Marsh to the south, and the surrounding hills to the east and west is urbanized (Gestrin 1963, Ravbar 2002, Rebernik 2004, Tiran 2016, Nared et al. 2017).

\section{Geodiversity of the Ljubljana Basin}

The wider Ljubljana area can be divided into four typical morphological units: the elevated

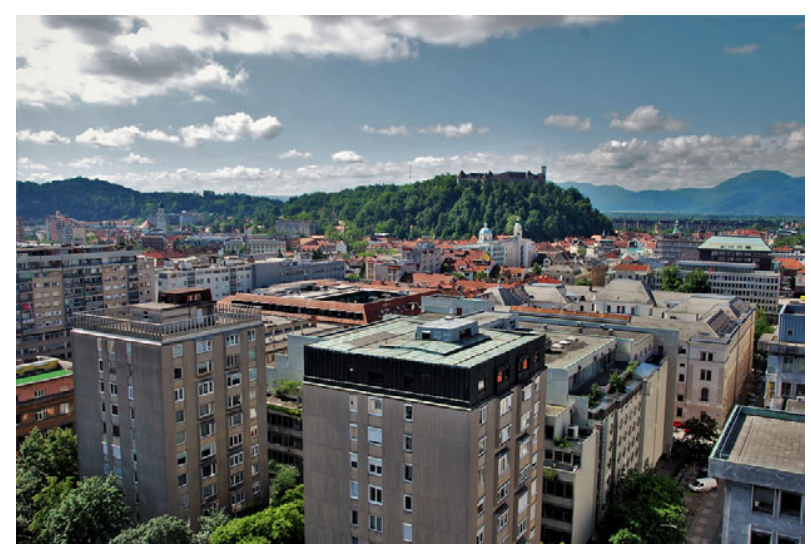

Fig. 4. The centre of Ljubljana was built on the bank of Ljubljanica River at the foot of Castle Hill (photo: J. Tičar). margins of the Polhov Gradec Hills to the west, the Sava Hills (including Golovec Hill) to the east, the level Ljubljana Marsh to the south, and the Ljubljana Plain to the north (Fig. 1).

The edges of the rugged Polhov Gradec and the Sava hills cut into Ljubljana's urban territory. Their slopes are broken up by narrow gorges and valleys. Claystones and sandstones make up the majority of the hilly area, resulting in frequent erosion and landsliding. The Castle Hill (Table 1, Fig. 7) in the very centre of the city is also threatened by landslides (Komac, Zorn 2007, Dobravc 2007, Zorn, Komac 2008). Large valleys with wide and flat bottoms are wet and occasionally flooded (e.g., along Pržanc, Glinščica, Gradaščica, and Grivka streams). Valley edges feature hydrologically non-active parts of fossil alluvial fans, which were deposited by watercourses during the Pleistocene glaciation (Šifrer 1984). Alluvial terraces were formed at several levels. In the west the oldest Pleistocene terrace rises $50 \mathrm{~m}$ above its surroundings. It is partly consolidated into conglomerate. A lower Pleistocene terrace between the Žeje and Dolgi Most neighbourhoods rises $5 \mathrm{~m}$ above the surrounding area. The lowest Pleistocene terrace is morphologically the same as its surrounding fine-grained Holocene sediments but it is distinguished from them by rougher and gravellier material. Terraces along the river provided a good flood-safe area for the development of the city (Šifrer 1984). The city centre is located on a river bed of the Ljubljanica River.

The Iška River flows into the Ljubljana Marsh from a $10 \mathrm{~km}$ long and up to $500 \mathrm{~m}$ deep canyon (Table 1, Fig. 7) . There are several caves on the steep rocky slopes, the longest is $66 \mathrm{~m}$ long Kevderc Cave at Krvava Peč (Cave Register of Speleological Association of Slovenia 2016). Overall, the dolomite slopes are rarely broken up by ravines; rockfalls are much more common. In the lower part, the canyon narrows into the Iška Gorge with vertical walls. An extensive alluvial fan was formed in the Pleistocene at the outflow from the canyon, while a recent Holocene fan was formed north of Tomišelj (Šifrer 1984). Several springs, known as the marsh springs, can be found at the contact of the permeable gravel fan of the Iška River and the poorly permeable fine-grained marsh sediments. They are located between Ig and Podkraj, with Strahomer Spring (Table 1, Fig. 7) 
Table 1. List of 20 geosites in Ljubljana and its surroundings.

\begin{tabular}{|c|l|l|c|}
\hline ID & \multicolumn{1}{|c|}{ Geoheritage name } & Geomorphological interest & $\begin{array}{c}\text { Included in the } \\
\text { Register of Natural Values }\end{array}$ \\
\hline 1 & Castle Hill & landslides & yes \\
\hline 2 & Tivoli, Rožnik and Šiška Hill & fluvial relief & yes \\
\hline 3 & Ljubljanica Terrace & alluvial terrace & no \\
\hline 4 & Vrhovci-Brdo Terrace & conglomerate alluvial terrace & no \\
\hline 5 & Glinščica River & floodplain & no \\
\hline 6 & Stranska vas Fan & alluvial fan & yes \\
\hline 7 & Ljubljanica River & karst river & no \\
\hline 8 & Sava Terrace & alluvial terrace & no \\
\hline 9 & Toško Čelo Hill & fluvial relief & yes \\
\hline 10 & Plešivica Hill & isolated carbonate hill & yes \\
\hline 11 & Mali plac pri Bevkah Wetland & wetland & yes \\
\hline 12 & $\begin{array}{l}\text { Sava, Ljubljanica and Kamniška Bistrica River } \\
\text { confluence }\end{array}$ & point bar & yes \\
\hline 13 & Šmarna gora Hill & isolated hill & yes \\
\hline 14 & Podpeč Lake & karst lake & yes \\
\hline 15 & Preserje Polje & karst polje & no \\
\hline 16 & Strahomer Spring & spring & yes \\
\hline 17 & Iška Fan & alluvial fan & yes \\
\hline 18 & Iška Canyon & canyon & no \\
\hline 19 & Mount Krim & karst surface & yes \\
\hline 20 & Pekel Waterfalls & waterfalls & \\
\hline
\end{tabular}

among the most prominent (Rman, Novak 2016). Borovniščica Stream flows from a $1 \mathrm{~km}$ long canyon best known for its five attractive waterfalls.

The Ljubljanica River meandered across the Ljubljana Marsh plain in the past, but it is fully channelized today. Periodic floods occur almost every year (Fig. 5) while more extensive flooding mostly threats the areas which were settled in the $20^{\text {th }}$ century or later (Komac et al. 2008). In several places, isolated carbonate hills rise up to $100 \mathrm{~m}$ above the plain (Pavšič 2008). Their edges are densely settled than the higher rocky forested parts. In the Ljubljana Marsh only isolated patches of raised bogs are preserved, such as the Kozlerjeva gošča (the Kozler thicket) south of Črna vas and the Mali Plac (Table 1, Fig. 7) nature reserve near Bevke (Smrekar et al. 2014).

To the south, the high Dinaric Mountains rise above the Ljubljana Marsh. They are characterized by karst features, such as karrens, dolines, collapse dolines, and caves. Two large karst poljes with a periodically flooded flat bottom can be found at Podpeč and Preserje (Table 1, Fig. 7). Sinking streams meander across them; they are fed by the karst springs (Gams 2003).

\section{The Ljubljana Marsh}

An extensive $\left(160 \mathrm{~km}^{2}\right)$ flood plain called the Ljubljana Marsh developed south of Ljubljana at the intersection of the Alpine and Dinaric regions. It is a tectonic depression with $200 \mathrm{~m}$ deep layers of gravel, sand, and clay. It is a cultural landscape with one of the largest complexes of wetland meadows in Slovenia, which has been protected as a nature park since 2008 (the Ljubljana Marsh Landscape Park, Zorn, Šmid Hribar 2012). During the Pleistocene, the area was often covered by a lake, and during the Holocene the lake covered the area until around the mid-second millennium BC (Županek 2005, Velušček 2010). It is crossed by several streams fed by karst springs to the south and west (the Iščica and Bistra rivers, and Retovje and Močilnik springs) and by surface streams from the karst hinterland to the south (the Iška and the Borovniščica rivers) north (the Podlipščica, Drobtinka, Radna, Gradaščica, and Glinščica streams) and east (the Škofeljščica and Grivka streams).

The Ljubljana Marsh has been settled at least since the Neolithic, when pile-dwellers lived in 


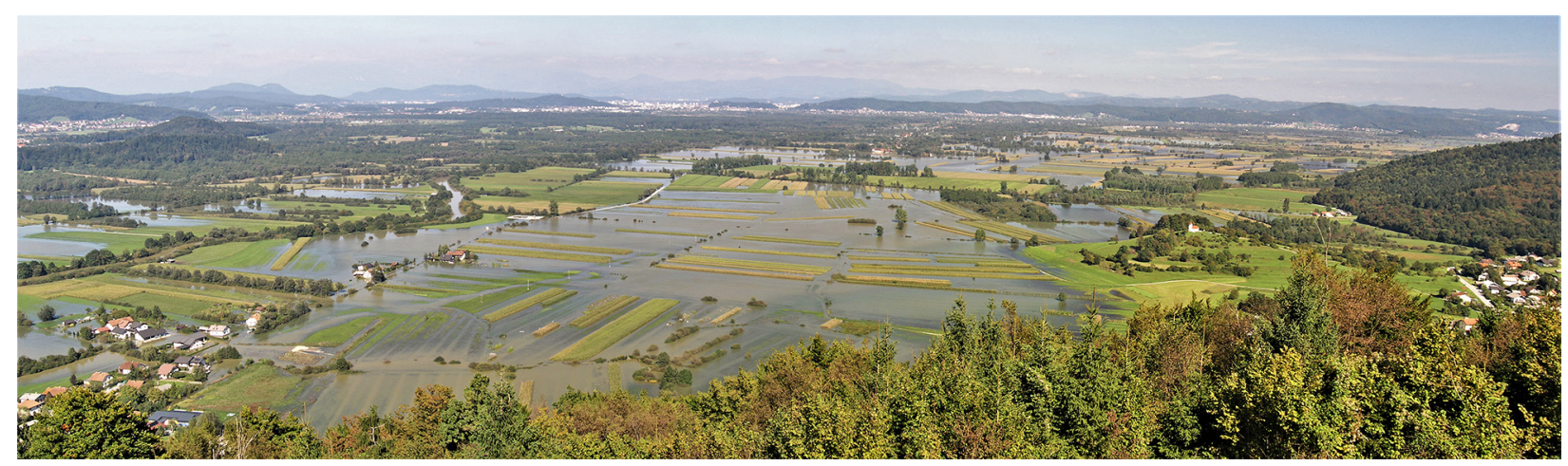

Fig. 5. Periodic floods are one of major restrictive factors for urbanization of the Ljubljana Marsh area (photo: B. Komac).

the area. Their pile-dwellings, which were raised above the shallow Holocene lake, have been on the UNESCO list of cultural heritage sites since 2011 as part of the nomination "Prehistoric Pile Dwellings around the Alps" (UNESCO, 2011).

The first major alterations to the Ljubljana Marsh were made by the Romans, who partly changed the course of the Ljubljanica River, in order to improve the river's navigability, especially for transport between the quarry at Podpeč (southern edge of the marsh) and the settlement of Emona (Zorn, Šmid Hribar 2012).

Key changes in the landscape occurred in the second half of the $18^{\text {th }}$ century, when the marsh was drained by number of canals to obtain agricultural land and for later settlement. In 1780 the Gruber Canal was dug in order to accelerate drainage; since then, Castle Hill in the centre of Ljubljana has been an island. The main drainage activities were completed in 1829 , which was followed by settlement of the marsh. In the 1820s, a road was built through the marsh and a railroad in 1857. Due to new deposits from the Ljubljanica River, major drainage work had to be repeated several times, but the marsh was never completely drained and is the largest Slovenian flood area. The area is characterized by two types of floods: karst floods that occur two or three times a year and are caused by the major karst hinterland to the south, and by flash floods caused by streams from the Polhov Gradec Hills to the northwest.

Important alteration of the landscape was also caused by intensive peat harvesting. Peat covered nearly $70 \%$ of the land 150 years ago, but one can hardly find any today. The peat was usually 1 to $2 \mathrm{~m}$ thick, and in extreme cases even up to 6 $\mathrm{m}$ thick. Peat harvesting resulted in lowering of the surface, which led to greater flood risk (Zorn, Šmid Hribar 2012).

The Ljubljana Marsh area remained uninhabited due to the continuous flood hazard from the Ljubljanica River and flash floods from streams from the nearby hills (Kotarac 1999, Smrekar et al. 2014). In 1828 the road to Ig was built, and in 1830 planned settlement began. New settlements were built in what are now Črna vas and Lipe, and colonization of the Ljubljana Marsh culminated in the era of the peat industry from the 1860 s to the $1880 \mathrm{~s}$.

In the 1950s and 1960s, the Ljubljana Marsh was agrarian and sparsely populated. In the 1960s, gradual expansion of Ljubljana began as a result of two types of urbanization: planned and uncontrolled. Most buildings built without permits were legalized in 1990, and this increased pressure on the southern edge of Ljubljana, which is at risk of flooding. The number of residents in flood-prone areas rose from a few thousand to over thirty thousand in just a few decades (Gašperič 2004, Komac et al. 2008).

Around 1990, the initiative for construction of housing and other buildings in Ljubljana was taken over by construction companies. Organized construction of single-family houses and housing estates flourished (Rebernik 1999).

\section{The Ljubljana Plain}

By frequently changing its course in the past, the Sava River eroded its banks and moved the deposited material across the Ljubljana Plain. Since the mid- $19^{\text {th }}$ century, it has been regulated several times, its course has been straightened, and its gradient has been increased to reduce flooding 
along the river (Radinja 1951, Smrekar 2007). In contrast to the Ljubljanica River on the Ljubljana Marsh, whose natural course meandered across the plain, transporting only fine-grained material, the gravel-carrying Sava River had a braided channel with large quantities gravel deposits in its bed. Only a few areas of braided channels have been preserved to date at Tacen, Jarše, and Podgrad. In the Ljubljana Plain, the Ljubljanica River has a more natural course than the Sava and is gradually already leaving the urbanized area in this section. To the east of the Fužine neighbourhood, the course of the Ljubljanica River is increasingly less regulated; the banks are more natural, with natural erosion and accumulation processes taking place on them. The course of the river creates large meanders, along which there are many sloughs. Today, the Ljubljanica and Sava rivers cut into their Pleistocene deposits, creating terraces at several levels separated with terrace treads (Fig. 6). The Ljubljanica River flows into the Sava River at Podgrad, where they are joined by the Kamniška Bistrica River, creating a confluence of three major rivers (Table 1, Fig. 7).

\section{Discussion and conclusions}

The Ljubljana area and its vicinity are characterized by high geodiversity and, therefore high special geoheritage value. The fundamental reason for this are its diverse geology and relief as various geological, lithological, and geomorphological types that are present in the surroundings. The relief was influenced by tectonic, glacial, hydrological and other processes, including high anthropogenic impact. The majority of the already recognized geoheritage (Table 1, Fig. 7) can be found in the Ljubljana Marsh Landscape Park (Fig. 7) that extends to the south of Ljubljana. The area is easily accessible and has received much attention of geoheritage-related tourism, which mostly focuses on the remnants of the marsh, springs and geological sites but less on geomorphosites in the city itself (Smrekar et al. 2016b).

Other major areas with special geoheritage values in Ljubljana area are the Polhov Gradec Hills Landscape Park in the west, the Zajčja Dobrava Landscape Park (Fig. 7) in the east, and Landscape Park Tivoli, Rožnik and Šiška Hills (Table 1, Fig. 7), close to the city centre (Smrekar

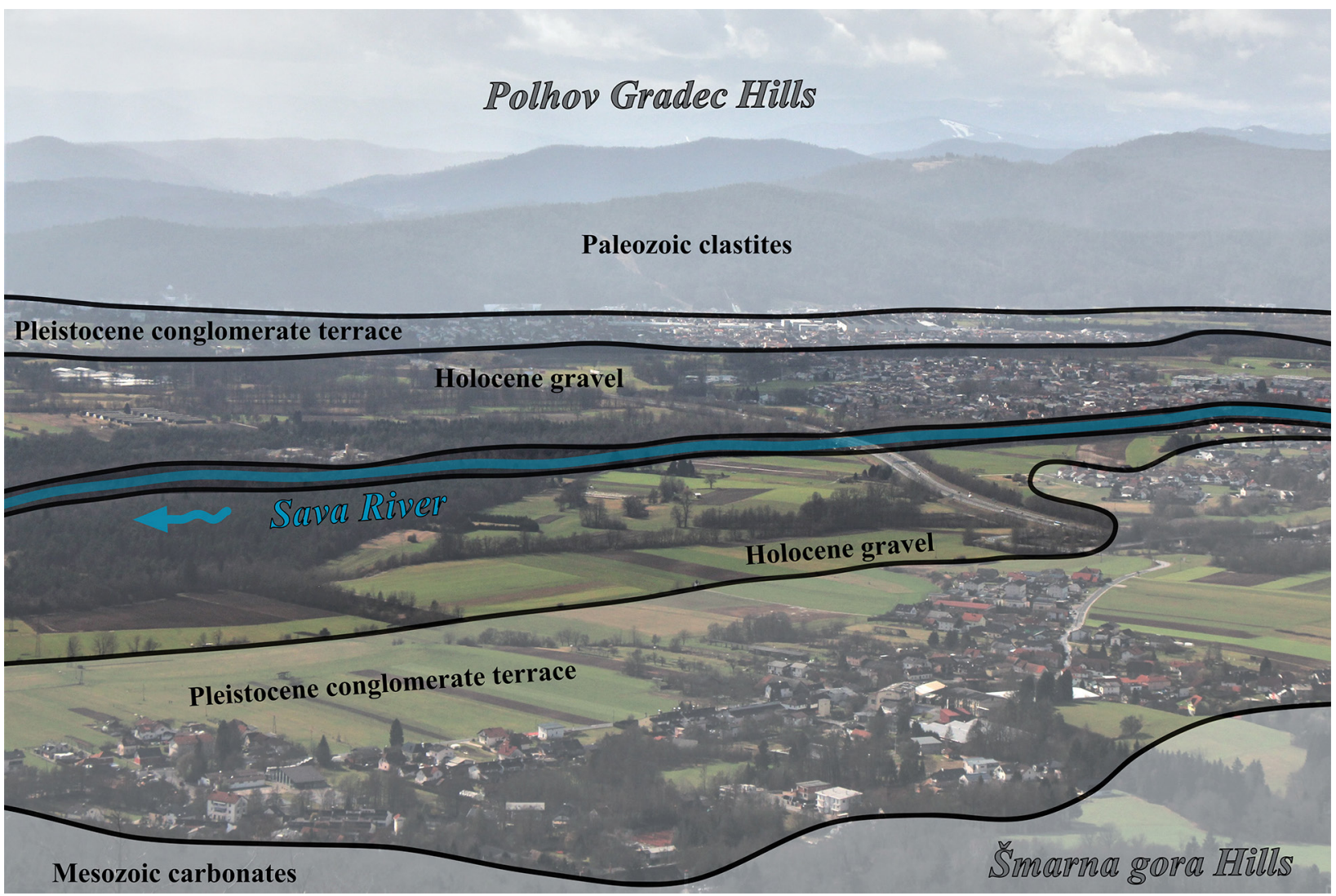

Fig. 6. System of river terraces in the northwest part of the Ljubljana Plain (photo: M. Pavšek). 
et al. 2016a). Therefore, the latter park is the most visited, has well developed tourist infrastructure (e.g. paved paths, playgrounds, sport facilities, food services) and is easily accessible to all kinds of visitors. There are also some educational information boards, but they are focused primarily on culture and biodiversity. Other two parks are less developed in this sense, with less infrastructure, but offer different experiences.
Until recently, geoheritage have not received much attention in the city and its surroundings. Within our study we have prepared a list of 20 important geomorphosites and compared it with the Register of Natural Values (SEA 2017). Only 12 geoheritage sites have already been recognized as natural values. Urban tourism has not yet integrated these features although they can
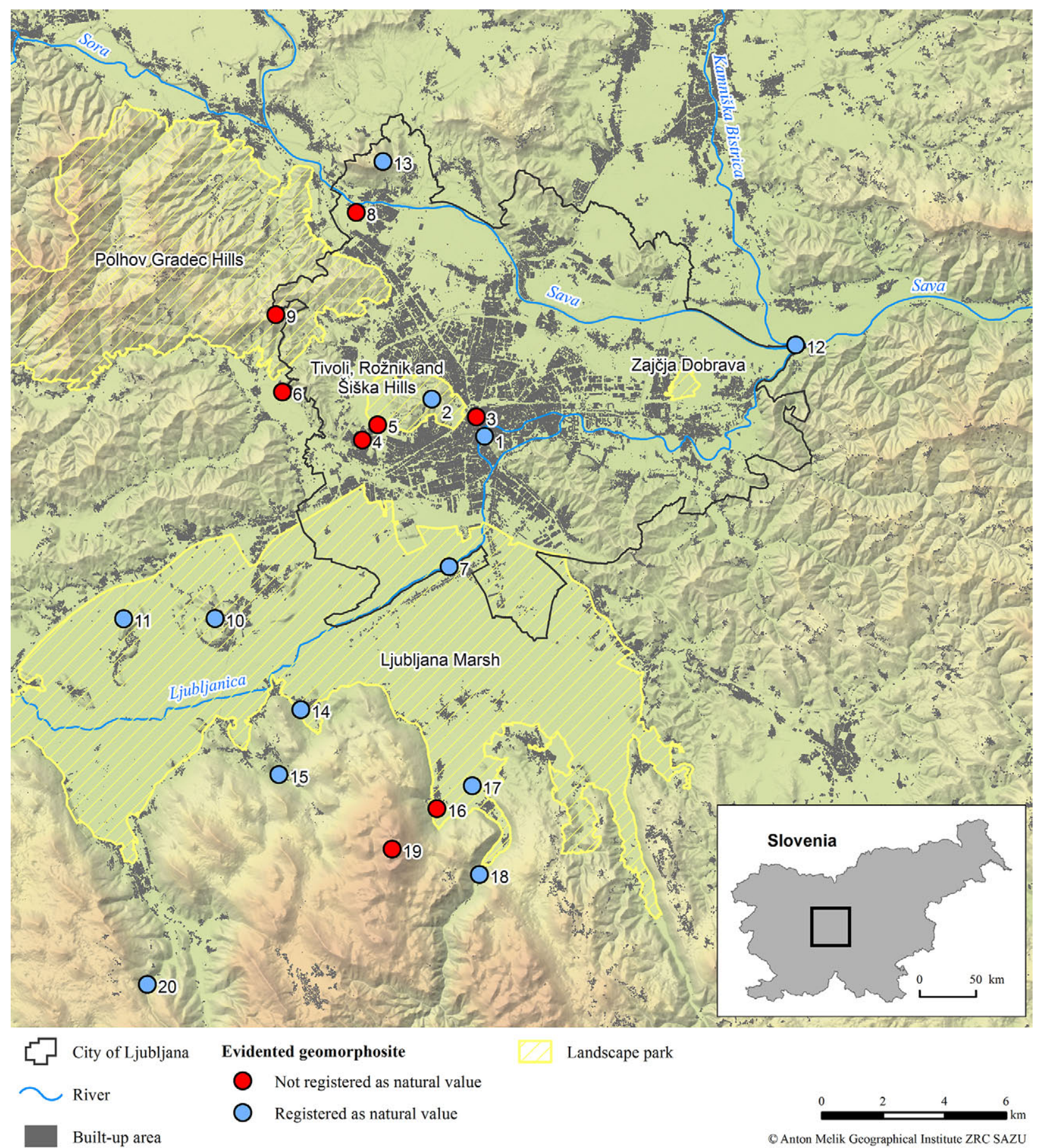

Landscape park

Not registered as natural value

Fig. 7. Map of geoheritage sites from Table 1. 
offer an added value for modern educational and recreational urban tourism.

With this review we wanted to raise awareness about the high geodiversity and high geoheritage importance in the Slovenian capital to bridge the gap between pre-modern and modern comprehension of urban landscape where geoheritage constitutes its component part. A proper overview of geoheritage in Ljubljana is not only important for tourism, it can also help us to learn and understand natural processes and to adapt to them.

A historical review of settlement development clearly shows how people adapted to natural circumstances in early history by relocating to the most suitable spots that offered food and protection from floods. Due to technological development, various interventions were later made (e.g., regulation of the Ljubljanica River in Roman times, and earthquake-resistant construction in second half of $20^{\text {th }}$ century). These measures caused major changes in the area (e.g., draining the marsh and the clearance of bog pits). However, some issues still remain open or are emerging as new problems because some human influence does not follow natural properties of the area and is thus not sustainable (e.g., settlement in flood zones). In the past the city growth was mainly determined by the hydrological conditions of the area, while today the main factor is the relief of the Ljubljana Basin.

A variety of natural circumstances prevents the easy transfer of practices from one area to another, which makes spatial planning challenging. For example, the northern part of Ljubljana has a completely different bedrock structure than the southern part. On the other hand, the diversity of the area makes it interesting for researchers, other experts, and even tourists, who can find various examples of geomorphosites in a small area.

\section{References}

Borghi A., Berra V., D’Atri A., Dino G.A., Gallo L.M., Giacobino E., Martire L., Massaro G., Vaggelli G., Bertok C., Castelli D., Costa E., Ferrando S., Groppo C., Rolfo, F., 2015. Stone materials used for monumental buildings in the histrorical centre of Turin (NW Italy): architectonical survey and petrographic characterization of Via Roma. In: Pereira E., Marker B.B., Kramar S., Cooper B.J., Schouenborg B.E. (eds), Global Heritage Stone: Towards International Recognition of Building and Ornamental Stones.
Geological Society, London: 201-218. DOI: 10.1144/ SP407.20.

Bratož R., Vilfan S., Melik V., Ferenc T., Pak M., 1992. Ljubljana: zgodovina. In: Javornik M. (ed.), Enciklopedija Slovenije 6. Mladinska knjiga, Ljubljana: 220-236.

Brilha J., 2016. Inventory and Quantitative Assessment of Geosites and Geodiversity Sites: a Review. Geoheritage 8: 119-134. DOI 10.1007/s12371-014-0139-3.

Buhay D.N., Best L.A., 2015. Informal Learning at Stonehammer and English Riviera Geoparks. Geoheritage 7: 165-175. DOI 10.1007/s12371-014-0125-9.

Buser S., 1974. Guidebook of sheet Ribnica, Basic geological map of Yugoslavia 1:100,000. Federal Geological Survey of Beograd, Beograd.

Buser S., 2009. Geological map of Slovenia 1:250.000. Geological Survey of Slovenia, Ljubljana.

Cayla N., 2010. Les processus de construction de géotourisme alpin. Téoros. Revue de recherche en tourisme 29(2): 15-25. DOI 10.7202/1024867ar.

Cave Register of Speleological Association of Slovenia, 2016. Speleological Association of Slovenia. Ljubljana.

Ciglič R., Perko D., 2013. Europe's landscape hotspots. Acta geographica Slovenica 53(1): 117-139.

Coratza P., Giusti C., 2005. Methodological proposal for the assessment of the scientific quality of geomorphosites. Italian Journal of Quaternary Sciences 18(1): 307-313.

Djurić B., Rižnar I., 2017. The rocks for Emona. In: Vičič B., Županek B. (eds), EMONA MM: urbanisation of space - beginning of a town. Mestni muzej, Ljubljana: 121-144.

Dobravc M., 2007. Ocena ogroženosti Mestne občine Ljubljana zaradi plazov. Online: www.ljubljana.si/file/405358/ ogrozenost_mol_poplave_dobravc_2007.pdf (accessed 10 March 2017).

Erhartič B., 2010a. Conserving geoheritage in Slovenia through geomorphosite mapping. In: Regolini-Bissig G., Reynard B., (eds), Mapping geoheritage. Institute de géographie, Université Lausanne, Laussane: 47-63.

Erhartič B., 2010b. Geomorphosite assessment. Acta geographica Slovenica 50(2): 295-319. DOI 10.3986/AGS50206.

Erhartič B., 2012. Geomorfološka dediščina v Dolini Triglavskih jezer. Založba ZRC, Ljubljana.

Erhartič B., Zorn M., 2012. Geodiversity and geomorphosite research in Slovenia. Geografski vestnik 84(1): 51-63.

European Green Capital, 2016. Online: http://www.greenljubljana.com (accessed 15 March 2017).

Frey M.-L., 2012. From a pit to a visitor centre as geotourism attraction and lighthouse of the tourist destination Odenwald: Building up a sustainable infrastructure at the Messel pit world heritage site, Geo-Naturepark Bergstraße-Odenwald, Germany. In: Sá A. A., Rocha D., Paz A., Correia V., (eds), Proceedings of the $11^{\text {th }}$ European Geoparks Conference. AGA Associação Geoparque Arouca, Arouca: 121-122.

Gams I., 2003. Kras v Sloveniji v prostoru in času. Založba ZRC SAZU, Ljubljana.

Gaspari A., 2014. Prehistoric and Roman Emona: a guide through the archaeological past of Ljubljana's predecessor. Muzej in galerije mesta Ljubljana, Ljubljana.

Gašperič P., 2004. The expansion of Ljubljana onto Ljubljansko barje moor. Acta geographica Slovenica 44(2): 7-33. DOI 10.3986/AGS44201.

Gestrin F., 1963. Oris zgodovine Ljubljane od XVI. do XVIII. stoletja. Kronika 11(3): 139-148.

Gestrin F., 1989. Ljubljana - nastanek mestne naselbine. Zgodovinski časopis 43(4): 473-476. 
Grafenauer B., 1963. Ljubljana v srednjem veku. Kronika, časopis za slovensko krajevno zgodovino 11(3): 129-139.

Grad K., Ferjančič L., 1976. Guidebook of sheet Kranj, Basic geological map of Yugoslavia 1:100.000. Federal Geological Survey of Beograd, Beograd.

Gray M., 2013. Geodiversity: valuing and conserving abiotic nature. Willey-Blackwell, Chichester.

Henriques M.A., Tomaz C., Sá A.A., 2012. The Arouca Geopark (Portugal) as an educational resource: A case study. Episodes 35(4): 481-488.

Hobléa F., 2009. Karstic geomorphosites: managing subterranean natural-cultural heritage sites. In: Reynard E., Coratza P., Regolini-Bissig G. (eds), Geomorphostites. Verlag Fredrich Pfeil, München: 189-200.

Hose T.A., Marković S.B., Komac B., Zorn M., 2011. Geoturism - A short introduction. Acta geographica Slovenica 51(2): 339-342. DOI 10.3986/AGS51301.

IUCN, 2017. Geoheritage. Online: https://www.iucn.org/ theme/protected-areas/wcpa/what-we-do/geoheritage (accessed 14 March 2017)

Komac B., Natek K., Zorn M., 2008. Geografski vidiki poplav v Sloveniji. Založba ZRC, Ljubljana.

Komac B., Zorn M., 2007. Pobočni procesi in človek. Založba ZRC, Ljubljana.

Komac B., Zorn M., Erhartič B., 2011. Loss of natural heritage from the geomorphological perspective - Do geomorphic processes shape or destroy the natural heritage? Acta geographica Slovenica 51(2): 339-342. DOI 10.3986/ AGS51305.

Kotarac M., 1999. Kartiranje habitatnih tipov na Ljubljanskem barju. Center za kartografijo favne in flore, Miklavž na Dravskem Polju.

Melik A., 1930. Razvoj Ljubljane. Geografski vestnik 5: 93-137.

Nared J., Bole D., Breg Valjavec M., Ciglič R., Goluža M., Kozina J., Razpotnik Visković N., Repolusk P., Rus P., Tiran J., Černič Istenič M., 2017. Central Settlements in Slovenia in 2016. Acta geographica Slovenica 57(2): 7-32. DOI 10.3986/AGS.4606.

Necheş I.-M., 2016. Geodiversity beyond material evidence: a geosite type based interpretation of geological heritage. Proceedings of the Geologists' Association 127(1): 78-89. DOI 10.1016/j.pgeola.2015.12.009.

Novšak M., Beljakov Zidanšek I., Vojakovič P., 2017. The decline of the pre-Roman settlement at Tribuna - deliberations on the possibility of settlement discontinuity between the final phase of the La Téne [sic] settlement and the Roman military camp. In: Vičič B., Županek B. (eds), EMONA MM: urbanisation of space - beginning of a town. Mestni muzej, Ljubljana: 9-52.

Ogrin D., 2010. Physical-geographical factors relevant for the development of Ljubljana. In: Krevs M., Djordjević D., Pichler-Milanović N. (eds), Challenges of spatial development of Ljubljana and Belgrade. GeograFF 8: 27-36.

Orožen Adamič M., 1970. Kako naj vrednotimo pokrajino? Proteus 33(4): 152-156.

Pak M., 1992. Ljubljana. In: Javornik M. (ed.), Enciklopedija Slovenije 6. Mladinska knjiga, Ljubljana: 218-220.

Palacio-Prieto J.-L., 2015. Geoheritage within cities: urban geosites in Mexico City. Geoheritage 7: 365-373. DOI 10.1007/s12371-014-0136-6.

Panizza M., 2001. Geomorphosites: concepts, methods and examples of geomorphological survey. Chinese Science Bulletin 46: 4-5. DOI 10.1007/BF03187227.

Pavšič J., 2008. Neživi svet Ljubljanskega barja: geologija barja in njegovega obrobja. In: Pavšič J. (ed.), Ljubljansko barje: neživi svet, rastlinstvo, živalstvo, zgodovina in naravovarstvo. Društvo Slovenska matica, Ljubljana: 15-16.

Perko D., Ciglič R., 2015. Slovenia as a European landscape hotspot. Acta Geobalcanica 1(2): 45-54. DOI 10.18509/ AGB.2015.05.

Perko D., Hrvatin M., Ciglič R., 2017. Determination of landscape hotspots of Slovenia. Acta geographica Slovenica 57(1): 7-29. DOI 10.3986/AGS.4618.

Pica A., Vergari F., Del Monte M., 2016. The Aeterna Urbs Geomorphological Heritage (Rome, Italy). Geoheritage 8: 31-42. DOI 10.1007/s12371-015-0150-3.

Pleničar M., 1963. Guidebook of sheet Postojna, Basic geological map of Yugoslavia 1:100.000. Federal Geological Survey of Beograd, Beograd.

Portal C., Kerguillec R., 2017. The shape of a city: geomorphological landscapes, abiotic urban environment, and geoheritage in the western world: the example of parks and gardens. Geoheritage 9: DOI 10.1007/s12371-0170220-9.

Pralong J.-P., 2005. A method for assessing the touristic potential and use of geomorphological sites. Géomorphologie: Relief, processus, environnement 11(3): 189-196.

Premru U., 1983. Guidebook of sheet Ljubljana, Basic geological map of Yugoslavia 1:100.000. Federal Geological Survey of Beograd, Beograd.

Radinja D., 1951. Sava na Ljubljanskem polju. Geografski vestnik 23: 67-84.

Ravbar M., 2002. Suburbanizacijske težnje v razvoju prebivalstva in delovnih mest $\mathrm{v}$ Ljubljanski mestni regiji. In: Gabrovec M. (ed.), Geografija Ljubljane. Založba ZRC, Ljubljana: 215-233.

Rebernik D., 1999. Socialna geografija Ljubljane. Faculty of Arts, University of Ljubljana, Ljubljana.

Rebernik D., 2000. Prebivalstveni razvoj po letu 1945. In: Gabrovec M., Orožen Adamič M. (eds), Ljubljana: geografija mesta. Ljubljansko geografsko društvo, Založba ZRC, Ljubljana: 25-38.

Reynard E., 2009. The assessment of geomorphosites. In: Reynard E., Coratza P., Regolini-Bissig G. (eds), Geomorphostites. Verlag Fredrich Pfeil, München: 63-71.

Reynard E., Fontana G., Kozlik L., Scapozza C., 2007. A method for assessing "scientific" and "additional values" of geomorphosites. Geographica Helvetica 62: 148-158. DOI 10.5194/gh-62-148-2007.

Rebernik D., 2004. Recent urbanisation trends: from suburbanisation to reurbanisation. Geografski vestnik 76(2): 53-63.

Ribarič V., 1982. Seismicity of Slovenia - catalogue of earthquakes (92 A.D. - 1981). Seismological Survey of the SR of Slovenia. Ljubljana.

Rman N., Novak M., 2016. 70 geological wonders of Slovenia. Geological Survey of Slovenia, Ljubljana.

SEA. Slovenian Environmental Agency, 2017. Ljubljana

Sharples C., 1993. Methodology for the identification of significant landforms and geological sites for geoconservation purposes. Forestry Commission Tasmania, Hobart.

Smrekar A., 2007. Divja odlagališča odpadkov na območju Ljubljane. Založba ZRC, Ljubljana.

Smrekar A., Šmid Hribar M., Tiran J., Erhartič B., 2014. Interpretacija okolja na primeru Ljubljanskega barja. Založba ZRC, Ljubljana.

Smrekar A., Šmid Hribar M., Erhartič B., 2016a. Stakeholder conflicts in the Tivoli, Rožnik Hill, and Šiška Hill Protected Landscape Area. Acta geographica Slovenica 56(2): 305-319. 
Smrekar A., Šmid Hribar M., Tiran J., Erhartič B., 2016b. A methodological basis for landscape interpretation: the case of the Ljubljana Marsh. Acta geographica Slovenica 56(2): 279-290.

SORS. Statistical Office of the Republic of Slovenia, 2016. Ljubljana.

Stepišnik U., 2017. Vrednotenje geodiverzitete in trajnostni razvoj. In: Lampič B., Zupančič J. (eds), Raziskovalno-razvojne prakse in vrzeli trajnostnega razvoja Slovenije. Znanstvena založba Filozofske fakultete Univerze v Ljubljani, Ljubljana: 115-126.

Stepišnik U., Repe B., 2015. Identification of geodiversity hotspots on example of the Rakov Škocjan Landscape Park. Dela 44: 45-62. DOI 10.4312/dela.44.3.45-62.

Stepišnik U., Trenchovska A., 2017. A new quantitative model for comprehensive geodiversity evaluation: the Škocjan Caves Regional Park, Slovenia. Geoheritage 9. DOI 10.1007/s12371-017-0216-5.

Šifrer M., 1984. New findings on the geomorphological development on the Ljubljansko barje. Acta Geographica 23(1): 5-54.

Tiran J., 2016. Measuring urban quality of life: case study of Ljubljana. Acta geographica Slovenica 56(1): 57-73. DOI: 10.3986/ags.828.

Trenchovska A., Stepišnik U., 2017. The quantitative geodiversity model applied on upper Pivka karst, Slovenia. In: Buzjak N., Paar D. (eds), Zbornik sažetaka / International conference "Geodiversity, geoheritage and geotourism in karst areas", Faculty of Science, University of Zagreb, Zagreb: 45-48.

UNESCO, 2011. Prehistoric Pile Dwellings around the Alps: World Heritage nomination. Online: http://whc.unesco. org/uploads/nominations/1363.pdf (accessed 14 March 2017).

Velušček A., 2010. Koliščarji: o koliščarjih in koliščarski kulturi Ljubljanskega barja. Založba ZRC, Ljubljana.

Wiedenbein F.W., 1994. Origin and use of the term "geotope" in German-speaking countries. In: O'Halloran D., Green D., Harley C., Stanley M., Knill J. (eds), Geological and Landscape Conservation. Geological Society, London: 117-120.

Zorn M., Komac B., 2008. Zemeljski plazovi v Sloveniji. Založba ZRC, Ljubljana.

Zorn M., Šmid Hribar M., 2012. A landscape altered by man as a protected area: a case study of the Ljubljana Marsh (Ljubljansko barje). Ekonomska i ekohistorija 8: 45-61.

Zouros N., 2004. The European Geoparks Network. Episodes 27(3): 165-171.

Zwolinski Z., 2004. Geodiversity. In: Goudie A.S. (ed.), Encyclopedia of Geomorphology. Routledge, London: 417-418.

Žerjal T., 2017. The bank of the Ljubljanica at Prule (Ljubljana) in the Augustan period. In: Vičič, B., Županek, B. (eds), EMONA MM: Urbanisation of Space - Beginning of a Town. Mestni muzej, Ljubljana: 53-69.

Županek B., 2005. Rimljani na Ljubljanskem barju. Življenje in tehnika 61(3): 20-25. 